Кристина Димовска

\title{
ЧУДНОПРИКАЗНАТА НА ЏОН ТОЛКИН
}

Апстракт: Името на расказот на Џон Толкин произлегува од еден стих од англосаксонскиот еп Беовулф, каде што се споменува т.н. чудноприказна, којашто се раскажувала (односно се пеела) за време на гозби, на кои се чествувале хероите од минатото. Џон Толкин се повикува на стихот Sellic Spell на англосаксонски јазик (односно Wondrous tale на современ англиски јазик или Чудноприказна во македонскиот препев на професорот Драги Михајловски на погореспоменатиот еп) за да ја пресоздаде, авторски и рекреативно (па и белетристички) приказната за Беовулф.

За да се воспостави релација или врската меѓу хипотекстот и хипертекстот (термини што ни Џон Толкин, ни Кристофер Толкин не ги нудат во коментарите кон текстот), Чудноприказната најпрвин била срочена на англосаксонски јазик.

Џон Толкин ги создава и ги „воведува“ ликовите на Андфренд/Анпис (Unfriend/Unpeace, Непријател/Кавгаџија, што веројатно претставува суптилна дисторзија или упатување на името на Унферт од Беовулф), Хендшу (Handshoe/Ракочевел, лик што треба да образложи зошто Беовулф е напуштен од сонародниците) и Ешвуд (Ashwood/Шумопепел, како упатување на чуварот на брегот).

Трудот го користи компаративниот метод.

Заклучокот упатува на инспиративноста на старите „заборавени“ епови и на нивното влијание врз креативниот процес при создавањето на „ново“ дело коешто би било поинтересно, подопадливо (за читање, а посебно за разбирање) за современата читателска публика.

Клучни зборови: Џон Р. $\quad$ Р. Толкин, Sellic Spell/Wondrous Tale/Чудноприказна, хипотекст, хипертекст, еп.

Да им се раскажува на потомците за делата и обичаите на славните луѓе е обичај стар од дамнина. Па дури и денес, нашето поколение, иако незаинтересирано, не пропушта да спомне кога нечие славно дело и благородна доблест и ќе го победи и надмине порокот, заеднички и за малите и за големите држави - неправдата и завидливоста. Но, иако нашите предци биле понаклонети кон дела достојни за паметење, а пред себе имало и поотворено поле за такви достигања, и кај нив се случувало на некој славен ум да му се признаат заслугите и доблеста не само поради благодарност или добронамерност, туку само за совеста да остане чиста.

(Такит, 1999, 57). 
Кристофер Толкин, во уводот или во образложението на Sellic Spell (Чудноприказна на македонски јазик) $)^{1}$ дава увид во белешката што ја оставил неговиот татко, Џон Толкин, за текстот, првично напишан на англосаксонски јазик. Чудноприказната би требала да претставува бајковидна рекреација на англосаксонскиот еп Беовулф, во која отсуствуваат херојските и псевдоисториските елементи од базичниот текст/хипотекст.

За да се воспостави релација или врска меѓу хипотекстот и хипертекстот (термини што ни Џон, ни Кристофер Толкин не ги нудат во коментарите кон текстот), Чудноприказната најпрвин била напишана на англосаксонски јазик. Џон Толкин ги создава и ги „воведува“ ликовите на Андфренд/Анпис (Unfriend/Unpeace, Непријателот/Кавгаџијата, што веројатно претставува суптилна дисторзија или упатување на името на Унферт од Беовулф), Хендшу (Handshoe/Ракочевел, лик што треба да образложи зошто Беовулф е напуштен од сонародниците) и Ешвуд (Ashwood/Шумопепел, како упатување на чуварот на брегот). ${ }^{2}$

Името на Беовулф треба да се толкува како кенинг: Bee-wolf (Пчеловолк), што упатува на хипотезата дека Џон Толкин не приклонил кон идејата за епот за Беовулф како одглас на бајките за херојот-мечка. ${ }^{3}$ Наместо тоа, решението на Џон Толкин се поврзува за медот што го крадел младиот Бивулф од фармерите, по што го добил и името.

Името на хипотекстот е изведено од стихот 1772, во препевот на Беовулф (1926 [2014]): „hwílum syllíc spell rehte æfter rihte rúmheort cyning“, односно од стихот 2109 од македонскиот препев: „напати силнодуховниот крал/нѐ чествуваше со чудноприказни чуени низ преданијата“" (курзив К. Д.). Syllic и sellíc се различни форми на истиот збор (K. Tolkien, 2014, 234) 4 и се однесуваат на оној вид песни што се рецитирале, се пееле или се изведувале како перформанс за време на гозби. Текстот на Џон Толкин веројатно бил пишуван на почетокот на 40-тите години на 20. век.

Текстот започнува со претстава на неименуван крал кој владее на Северот. Тој има една ќерка и посинок, којшто го нашле кралевите ловџии во мечкино дувло, на возраст од три години, а бил нем. Ова е Бивулф. Тој е претставен како типичен бајковид јунак: повлечен, тивок, но снажен и одлучен. Во англосаксонскиот јазичен контекст, текстот на Џон Толкин не е и

\footnotetext{
${ }^{1}$ Текстот на Џон Толкин не е преведен на македонски јазик. За целите на овој труд се користи преводот на стихот што го нуди професорот Драги Михајловски во неговиот препев на епот Беовулф на македонски јазик. Очигледно станува збор за неологизам. Во духот на Толкиновиот дискурс, веројатно подобро преводно решение би било „Чудесноприказна“ (ако се раководиме од уметничкиот „сенс“ за насловот Wondrous Tale) и во случајот со македонскиот препев на Беовулф, веројатно станува збор за зачувување на структурата на англосаксонскиот, односно, на македонскиот стих во превод.

2 Преводите на имињата на ликовите се мои.

3 За Џон Толкин, Беовулф е човекот мечка, убиецот на џинови, кој, за разлика од својот епски еквивалент, доаѓа од инаков свет: „од бајката“ (J. Tolkien, 2014, 149).

4 Бројот на страницата се дава во согласност со електронското издание на Чудноприказната.
} 
не може да се однесува на бајка во онаа смисла во којашто ние денес го разбираме и го толкуваме овој збор/жанр, туку попрво се однесува на „извештај“, на приказна, на известување. „Песната на поетот за успехот на Беовулф е spell““ (J. Tolkien, 2014, 231).

Меѓу првите противници на Бивулф е Брејкер (Breaker/Кршач, Уништувач, Рушител, како очигледно упатување на Брека од Беовулф), кој доаѓа од Сурфленд (Surfland, фиг. Земја на брановите - повторно упатување на натпреварот во пливање/морскиот мегдан со Брека). Како и во хипотекстот, така и тука, мегданот во пливање трае пет дена. Бивулф завршува како виновник за гневот на „никсите“, кои, во случајов, стојат на местото на „водомонструмите“ од Беовулф, односно, на рибите убијци и на морските чудовишта што ги пресретнуваат обајцата за време на натпреварот. На англосаксонски, овие демони биле подведени под именката nicor, односно на германските зборови - nix, nixy, кои се однесувале генерално на морски суштества. Но, овие не претставуваат пречка за Бивулф да ја надмине првата сериозна иницијација. По мегданот, тој ќе се најде во земја далеку на северот населена од Фини.

Текстот потем прави прескок од Бивулфовите млади години - кога овој веќе е созреан маж. И тука, како и во епот, е задржана стереотипната претстава за мажот како исклучителен над останатите (мажи, но и луѓе, во генерална смисла), таков, кој е немерлив по силата. Сигналот за врската со хипотекстот е одржана во мерата на неговата сила што одговара на триесет луѓe - бројот на панцири што ги носи епскиот Беовулф, но и неговата физичка крепост што соодветствува на силата на триесет мажи (Беовулф, 379-380). ${ }^{5}$

Од случајни и неименувани дворјани, Бивулф ќе слушне за величествената куќ $а$ што ја изградил некој крал во некоја далечна земја и која подоцна се споменува под називот Златна сала. Ова именување е очигледно упатување на кралската сала Хеорот, којашто, во Беовулф, често пати е врзана за симболот на златото и на светлината. ${ }^{6}$ Оваа куќа станала нашироко позната по гозбите и славењата, кои се случувале таму, но „куќата“ брзо била напуштена поради тоа што ја опсадил некој џин (ogre). Бивулф ова ќе го протолкува како повик за авантура (според терминологијата на Кембел), иако неговата иницијатива ќе биде „поздравена“ како лудост.

На патот до Златната сала, Бивулф ќе налета на Хендшу, чие име се врзува за ракавиците што ги носи (веројатна инсинуација на Гренделовата ракавица $)^{7}$, кои му овозможуваат натчовечки моќи. За разлика од Беовулф, кој, освен индиректната помош од побратимите во битката против Грендел и

\footnotetext{
${ }^{5}$ Сите упатувања на епот Беовулф се преземени од македонскиот препев.

6 Оваа Златна сала ќe прерасне во Златен дворец, престолнина на Теоден и Рохиримите, во Господарот на прстените.

7 Френдер (2008) предлага дека англосаксонската именка glof која се однесува на Гренделовата ракавица, може да се толкува како метафорична интерпретација за подуениот стомак на Грендел поради изедениот Хондскио. Името на вториот може да се преведе како ракавица. Ракавицата во Чудноприказната се споменува само попатно, во битката меѓу монструмот и херојот.
} 
директната помош од Виглаф во битката против змејот, Бивулф ја добива наклонетоста на Хендшу, кој решава да му се придружи во авантурата.

Обајцата се пресретнати од резервираниот Ешвуд, чиј опис потсетува на оној на чуварот од брегот во Беовулф. Но, за разлика од епот, во кој Беовулф е подложен на вербален тест, чија цел е да се откријат неговите вистински намери за пристигнувањето во Данска, Ешвуд не е олицетворение на мудриот и прониклив чувар, туку е само еден „обичен“ воин, кој, поради интерес, ќе им ce придружи на останатите двајца на патот до Златната сала. Она што е воочливо во Чудноприказната е отсуството на пословичните искази кои се провлекуваат низ Беовулф, а кои служат не само да се претстави моралниот код, кој е/бил генерално важечки за херојскиот начин на живот, туку и на сликовитата претстава на убедувањата/верувањата на ликовите (или, теориски кажано, на духот на едно време, отсликан преку врвната поетска умешност на епските пејачи).

Тројцата ќе се најдат во одаите на стариот белобрад крал, една од Толкиновите вообичаени претстави за кралската фигура (со акцент на Господарот на прстените, преку ликовите на белобрадиот Гандалф или на остарениот Теоден). Откако ќе се претстават, Бивулф и останатите двајца ќе разберат дека Грајндер (Grinder/Сечачот/Толчачот - јасно упатување на Грендел) е името на суштеството за чија глава кралот ќе даде богата награда. Но, Грајндер не е обичен човек, па затоа кралот ќе се најде во недоумие поради решителноста на Бивулф да се пресмета со овој непријател, особено ако се земе предвид колкумина пред него ги загубиле животите поради славо/златољубие. Хендшу и Ешвуд ќе ја поткрепат изјавата на Бивулф и ќе се изложат заедно со него на тест на силите против чудовиштето што ја мори Златната сала.

Тројцата ќе бидат поздравени од (неименуваната) кралица, но не и од Анфренд, кралевиот ковач, кој „од високо се гледаше себеси“ (J. Tolkien, 2014, 237). Ако се земе предвид дека Чудноприказната била напишана во раните 40-ти години на минатиот век, а вториот том: Двете кули (од трилогијата Господарот на прстените) бил објавен во 1954. година, тогаш може да се претпостави дека преку ликот на Унферт, Џон Толкин добил инспирација да го создаде ликот на Анфренд/Анпис, кој подоцна добива попрецизни контури и еволуира во ликот на Грима/Црвојазик, озлогласениот советник на кралот Теоден. Анфренд ќе го испровоцира Бивулф со истата намера како Унферт Беовулф, па затоа и „одбраната“ на вториот, не отстапува значајно од онаа на Беовулф. ${ }^{8}$ Џон Толкин само навидум го надминува анимозитетот меѓу епските пандани на своите ликови преку мотивот на прегратката. Таа, отпрво, е претставена како пријателски гест (метод на Бивулф да ги умири сомнежите

\footnotetext{
${ }^{8}$ Како што вели Такит: „Постои големо соперништво меѓу придружниците за тоа кој ќе го има првото место до првенецот, но и меѓу првенците - кој ќе има побројна и поприврзана придружба“" (Такит, 1999, 26-27). Ова навистина соодветствува и на однесувањето на Унферт, но и на Анфренд, кои секако дека би сакале да бидат „десната рака“ на кралот, што значи дека секој оној којшто би им застанал на патот во оваа нивна стратегија, би се сметал за недобредојден и за непријател.
} 
на Анфренд), за подоцна да се покаже дека прегратката била ироничен чин не на предавство [како бакнежот на Јуда], туку како театарски гест за божемното пријателство меѓу двата лика). Аргумент за ова постои во епизодата во која Анфренд го забележува зацрвенувањето на водата во мочуриштето на Грајндер, по што ќе помисли дека Бивулф ја загубил битката против Грајндеровата мајка: „а таа мисла не го растажи, затоа што не ја беше заборавил прегратката“ (J. Tolkien, 2014, 242; курзив К. Д.). Дополнителен аргумент е отпуштањето на јажето, епизода што отсуствува во хипотекстот, како одмаздољубив гест на Анфренд против срамот што го доживеал поради Бивулф, пред кралот. Со ова, Анфренд добива посебна улога во оваа епизода, која, во хипотекстот делумно им е доделена на „белокосите единомудреци“ (со исклучок на нивното одмаздољубиво настројство), ${ }^{9}$ односно на придружниците на Беовулф, и оваа техника покажува дека краткиот роман е посоодветен за претставување на некои морални дилеми на ликовите, што не е секогаш едноставна изведба во епскиот (стихуван!) текст.

Хипертекстот отклонува од својата основа со тоа што ги претставува Бивулф, Хендшу и Ешвуд како истовремено славољубиви, што значи дека на кралот му е дадена можноста, по своја волја, да избере кој ке се пресмета со Грајндер. Ешвуд се јавува прв и полага право тој да биде оној што ке го чека Грајндер во заседа, поради тоа што бил првиот што стапнал на кралевите земји. За тоа време, Бивулф и Хендшу ќе бидат сместени другаде (упатување на стих 1300: „Беовулф не бил таму [во Хеорот, К. Д.] бидејќи одделни одаи/ му биле брзо спремени по благо-дарувањето“; курзив К. Д.).

Со појавата на Грајндер во Златната сала станува очигледна двојната улога што ја игра Ешвуд: неговата резервираност го прави да биде близок до природата на чуварот на брегот, чија улога е да испитува, да се сомнева, да прашува, но неговото убиство од страна на Грајндер, го прави поблизок до ликот на Аешер од Беовулф, односно на првиот лик што умира од раката на Грендел, со таа разлика што меѓу Ешвуд и неименуваниот крал не постои претходно пријателство или сонародништво. ${ }^{10}$

Како што се очекува, кралот повторно ќе ги праша преостанатите двајца дали сѐ уште сакаат да си ги пресметаат силите со Грајндер. Редот е на Хендшу, затоа што тој бил првиот кој излегол од чамецот што ги довел него и

\footnotetext{
9 Придружниците на Беовулф попрво би се закитиле со титулата на страшливци, одошто на ликови со повредено его и чест.

${ }^{10}$ Истовремено е заводливо, но и опасно да се разгледува теоријата на побратимството во македонската народна култура, тема детаљно обработена од Весна Петреска во нејзината студија Побратимството во македонската народна култура. Заводливо е да се разгледа прашањето од причина што и во Беовулф и во Чудноприказната се третира некаква идеја или концепт на побратимство, којашто се подведува под називот commitatus. Имено, идејата за comitatus е поврзана за верноста/лојалноста кон кралот. Опасно е современиот концепт на побратимството, како што е третирано во трудот на Весна Петреска, да се подведе и доведе во исто и со исто значење, меѓутоа може да се претпостави за еволуција и прилагодување на лојалноста, на честа и традицијата во нови, посовремени услови. Повеќе да се види кај: Весна Петреска. 2019. Побратимството во народната култура: побратимството на Говедар Камен.
} 
Бивулф до земјите на кралот. Бивулф нема да настапи против оваа одлука, што ќе го натера, очигледно, лицемерниот Анфренд да заклучи дека првиов како да се радува што ќе му биде одложен часот на пропаста.

Како и Ешвуд, така и Хендшу ќе го загуби животот поради невнимание/страв од можноста од нападот на Грајндер. Докази за потфрлањето на обајцата се напуштеното копје и ракавиците, кои сведочат за неподготвеноста на Ешвуд и Хендшу, соодветно да одговорат на маките на кралот. Правилото на „трета среќа“ е она за што ќе се заложи Бивулф пред кралот. Тој ќе настапи со сличен манир како Беовулф, кој се обиде да го одврати Хротгар од патилата, со ветувањето дека ќе успее да ја елиминира заканата. Бивулф му порачува на кралот дека неговата смрт (на Бивулф) би можела да значи и спасение на кралот од незгодата да му понуди засолниште, а во случај да умре, тој, кралот, нема да биде обврзан да ги изврши погребалните почести. Зборовите на Бивулф соодветствуваат, до извесна мера, на стиховите 445-446 и 450-451, во кои Беовулф му се обраќа на Хротгар: „Никогаш не ќе треба/ телово да ми го закопуваш смртта ако ме земе“ и „Ослободен ќе бидеш/ од мачниот товар маката [sic] со телово“. Единствениот пословичен исказ што му е упатен на Бивулф до оваа епизода од текстот е пораката на кралицата: „Fate oft spareth him that fears him not“, односно „Судбината го спасува оној што не ѝ се плаши“ (J. Tolkien, 2014, 238). Исказот претставува упатување на поуката што ја искажува Беовулф во прераскажувањето на авантурата со Брека, во македонскиот препев во стиховите 572-573: „Често судбината/ го спасува несуденикот кога смелоста му е силна!“. Ако Беовулф го истакнува ова свое сознание како начин да се ободри самиот себеси за претстојните пакости на Грендел, тогаш исказот на кралицата ја врши истата функција, што покажува дека Бивулф ја ужива нејзината морална поддршка.

Битката меѓу Бивулф и Грајндер претставува стилски осиромашено прераскажување на истата епизода во епот. Она што се потенцира во прозниот хипертекст, а отсуствува во епскиот хипотекст, е настројбата и поставеноста на Анфренд кон подвизите на Беовулф. Ова, поправо, претставува луксуз што прозниот хипертекст го дозволува (подлабоко навлегување во психолошките диспозиции на ликовите и особено на идниот херој), што би било речиси невозможно или пак невообичаено во епскиот текст. Па така, при здогледувањето на откинатата рака на Грајндер (доказ за успешната елиминација), Анфренд нема што да прекаже и да рече. Ова значи дека неговата претходна наклонетост кон Бивулф е само игра или маска. За разлика од него, кралот е воодушевен од делото на, сега веќе, херојски докажаниот Бивулф, што ќе го натера да заклучи дека овој поседува сила не на човек, туку на мечка. Преку овој опис се упатува на потенцијалните корени на Беовулф како еп настанат од мотивот/легендата за херојот-мечка, според мислењето на Џон Толкин.

Бивулф се нафаќа да замине во престојувалиштето на Грајндер, за што му е ветена тројно поголема награда од кралот, доколку успешно ја отстрани заканата. Одлучено е Бивулф да замине во придружба на Анфренд како човек што добро ги знае тајните на Грајндеровото засолниште. Како подарок, 
Бивулф го добива фамозниот сјаен корсет од железни прстени, што очигледно соодветствува на „широкиот војнокорсет“ (стих 1443), кој подоцна, во Дружината на прстенот од трилогијата Господарот на прстените, се појавува како панцирот од митрил што Фродо го добива како подарок од Билбо.

Хронотопот на Грајндеровото засолниште е олицетворение на грозоморна претстава за место, каде што можат да живеат морските немани и чудовишта. Обајцата сопатници, како и во Беовулф, така и тука се пречекани од мртвата глава на Аешер/Ешвуд. На забелешката на Бивулф за очигледното присуство на непријателски сили, Анфренд ќе возврати со исказ што има пословична функција: „Let sleeping gods lie!“, што по значење соодветствува на српската пословица „Не дирај лава док спава“, односно на македонската „Не закачај ја мечката додека спие“. ${ }^{11}$ Анфренд ќе додаде дека справувањето со неколку непријатели истовремено може да се покаже како макотрпна задача, на што Бивулф ќе реплицира: „Many foes can give a man but one death“ (J. Tolkien, 2014, 241). ${ }^{12}$ Иако по структура не е пословичен, исказот е стегната варијанта на реплика или говор што би му одзел на Бивулф непотребно време пред мегданот, па во оваа смисла, исказот ја истакнува неговата подготвеност (претпазливост, или наравоучение од искуство) да се справи и без да ги потцени бариерите на патот, без разлика на нивниот број, природа или причина.

Во хипертекстот се јавува суптилна разлика во опремата што ја носи Бивулф. Наспрема воениот корсет, шлемот, опремата со „вепар-слики“ (Беовулф, 1453) и мечот Хрантинг, неговата хипертекстуална изведенка го носи корсетот на кралот, ракавиците на Хендшу и копјето на Ешвуд.

Бивулф решава да се спушти во мочуриштето со помош на јаже, епизода што потсетува на елфското јаже што Сем и Фродо го користат во Двете кули. ${ }^{13}$ Во Беовулф, монологот на херојот го претставува во светло на изолација: тој е одлучен сам да замине против Гренделовата мајка, без притоа да се потпре на помошта на присутниот Унферт, што е показател за

\footnotetext{
11 Друга соодветна македонска пословица би била, во дадениот контекст: „Кога мечка не ти гази лезето, не викај по неа“. Исто и: „Кога имаш маша, не ваќај го огно со рака, оти ќе те изгорит“ (Поленаковиќ и Пенушплиски, 1954).

${ }^{12}$ Паремиолозите (и не само тие) сметаат дека преводот на исказ или на израз од еден јазик на друг е тежок процес. Понекогаш воопшто и не мора и не е потребно да се даде превод. Сѐ е зависно од целта на трудот што се пишува и се публикува и од оној што има доволно здрав разум/,,сенс“/општа наобразба за да го увиди искажаното. Во случајов, преводот на исказот може да биде само условен: „Непријателите се многу. Смртта е една“.

${ }^{13}$ Сомнежот на Бивулф е преточен во сомнежот на Фродо за способностите на Сем, кои се однесуваат на правилното (цврсто) врзување на јажиња(та). Возможно е оваа епизода од Чудноприказната да послужила како некаква основа за онаа во Двете кули, колку и да се чини наивна.
} 
амбигвитетот на епскиот херој, кој е обележан од својот „често пати подривачки, антисоцијален индивидуализам““(Miller, 2000, 53). ${ }^{14}$

Хипертекстот ја следи интенцијата на авторот стилски да ја поедностави текстурата на Беовулф со задржување само на оние симболични претстави што требаат да ја исцртаат врската меѓу првичниот и последователниот текст односно меѓу хипо- и хипертекстот. Најчестите визуелни симболи за Гренделовата мајка упатуваат на нејзината волчја природа и нарав, што соодветствува на кенингот што се јавува и во хипертекстот, преку кој, оваа е именувана како „волчја водоsверка“ (Беовулф, 1506) и „волчја враг-жена“ (Беовулф, 1599).

Хипертекстот ја анулира божјата наклонетост (интервенција) што ја спасува главата на Беовулф („Синот Ектеофов.../ ќе го снемало сосем.../ да не му дадел панцирот помош потребна.../a и Небобогот во светоста/ да не му навестел триумф: мудар Мажовладарот,/ господарот горнонебесен заповедал гласно/ да победи праведниот и овој пак се исправил“; 1550-1556; курзиви К. Д.). ${ }^{15}$ Двата кенинга што визуелно отскокнуваат од текстот (во смисла дека го рушат наративниот тек со својата експресивност), очигледно упатуваат на живата и пркосна христијанска сила, која влијаела врз моделирањето на оваа епизода од хипотекстот; херојот не би победил доколку на негова страна не би стоел Бог. Случајот е инаков со Бивулф, кој очигледно единствено се има самиот себе во бојот против „водо-монструмката“ (неименуваната мајка на Грендел), а со тоа, неговата портретизација станува пороманескна, но помалку епска. Ракавиците на Ешвуд се покажуваат од полза при поместувањето на каменот што го дели Бивулф од подводната одаја на ранетиот Грајндер (епизода што, очигледно, отсуствува во хипотекстот) и што го дели од присвојувањето на главата на непријателот како знак на триумф.

Кршењето на мечот и зачувувањето на неговите останки не е ексклузивно место во Беовулф, туку поправо е споделено место во епиката и во некои херојски саги. Зачувувањето на искршените фрагменти, епизода што е клучна за статусот на Арагорн во Господарот на прстените, ќе му овозможи на Бивулф да се пресмета со Анфренд, кој, за разлика од неговиот пандан Унферт, има позиција на ковач во Чудноприказната. Израмнувањето на сметката меѓу обајцата служи, како што и запишал Џон Толкин, да се „дополнат“ оние сегменти во хипотекстот, кои бараат посебни интервенции или дообјаснувања. Ако хипотекстот го остава неказнет Унферт поради неговиот кукавичлук, тогаш хипертекстот го прави тоа вешто, преку постапката на Бивулф. Поради ваквиот третман, Анфренд ќе се вразуми и тој

14 Пожелно е да се воспостави разлика меѓу асоцијален и антисоцијален индивидуализам. Вториот е од опасниот вид во современите општества.

${ }^{15}$ Впрочем, Беовулф признава дека не би успеал без помошта на Бог (Беовулф, 16571658), што значи дека неговиот лик е компактен во свеста на запишувачот, односно, дека не постои дискрепанција во коментарите на нараторот и директниот говор/обраќање на ликот. 
ќе биде одговорниот за прековувањето на сабјата Гилденхилт, „крајсносабјата“, епизода што отсуствува во хипотекстот.

Бивулф се враќа назад во својата земја, на чудење на кралот, кој е изненаден од неговиот триумф: „But many a man has a treasure in his hoard that he knows not the worth of it. [You thought little of the foundling that was brought from the bear's den; yet you have earned some thanks for your fostering, such as it was]“/ „Понекогаш човек покрај себе има богатство за кое не е свесен. [За низок ме сметаше, спасен од мечкиното дувло, а сепак, ти сега ми благодариш зашто си ме спасил, оти го заслужив тоа]“" (J. Tolkien, 2014, 244). ${ }^{16}$

Последниов исказ на Бивулф е пословичен, условно, затоа што упатува на нашироко усвоеното сфаќање за вредноста на она што еден човек го поседува и за коешто станува благодарен и свесен само кога ќе го загуби. Дискурсот на хипертекстот е близок со оној на Господарот на прстените и ги користи ликовите (некои од нив), како еден вид писателски поход во создавање на оние ликови од романите на Џон Толкин. Очигледно, ако не и неоспорно, е дека содржината на сижето е од примарен интерес на Џон Толкин, како автор на фикција, а ако предвид се земат типот на дискурсот и релативната обемност на неговата (спомената) трилогија, тогаш не треба да изненадува што во нив квантитетот на пословични искази, или на други паремиолошки форми, е сосема ограничен.

\section{ЛИТЕРАТУРА}

\section{Кирилични изданија}

ПЕТРЕСКА, В. (2019). Побратимството во народната култура: побратимството на Говедар Камен. Скопје: Институт за фолклор „Марко Цепенков“".

ПОЛЕНАКОВИК,, Х., ПЕНУШЛИСКИ, К. (1954). Македонски народни умотворби. Том IV, книга 1, Пословици. Скопје: Книгоиздателство „Кочо Рацин“.

ТАКИТ, П. К. (1999). Германија; Агрикола. Прев. Весна Димовска-Јањатова Скопје: Култура.

\section{Латинични изданија}

Miller, Dean A. (2000). The Epic Hero. The John Hopkins University Press.

Pferenger, Andrew M. (2008). "Grendel's Glof. Beowulf Line 2085 Reconsidered". Philological Quarterly, vol. 87, No. 3-4.

Tolkien, J. R. R. (2014). Beowulf, a translation and commentary, together with Sellic Spell. Ed. Christopher Tolkien. Harper Collins Publishers.

Толкин, Џ. Р. Р. (2002б). Господарот на прстените. Д 2, Двете кули. Скопје: АЕА, Мисла.

\footnotetext{
${ }^{16}$ Преводов е мој.
} 
Kristina Dimovska

JOHN TOLKIEN'S SELLIC SPELL

Summary

John Tolkien took a specific verse from the Anglosaxon poem Beowulf in order to recreate the story of the epic hero Beowulf but he recreated the story and added different names to the protagonists and antagonists. His purpose was to re-create the storyline of the Beowulf epic for the possible purpose of transforming it into a short novel. His task was not easy: recreating Beowulf, which was originally written in Anglosaxon, was, probably, for the purpose of making the original text more entertaining and easier to understand and comprehend by the general public/audience. However, he took the original text and made adjustments to his short story which tells of different development of characters with similar names, but with somewhat different stories and journeys. 